\title{
Students' metacognitive awareness and physics problem solving ability and correlation between them
}

\author{
Siti Rahayu ${ }^{1}$, Erina Hertanti ${ }^{2 *}$ \\ ${ }^{1}$ Physics Education Department, Syarif Hidayatullah State Islamic University, Jakarta, Indonesia \\ ${ }^{2}$ Physics Education Department, Syarif Hidayatullah State Islamic University, Jakarta, Indonesia \\ *Corresponding Address: erina.hertanti@uinjkt.ac.id
}

\begin{tabular}{|c|c|}
\hline Article Info & ABSTRACT \\
\hline Article history: & en metacognitive awareness and \\
\hline $\begin{array}{l}\text { Received: November } 6^{\text {th }}, 2019 \\
\text { Accented. Anril } 18^{\text {th }} 2020\end{array}$ & $\begin{array}{l}\text { students' problem-solving ability level in direct current electricity concepts. } \\
\text { This study is conducted in } 2019 \text { in one of the Senior High Schools in South }\end{array}$ \\
\hline Published: October $29^{\text {th }}, 2020$ & Tangerang. There are 126 students of $12^{\text {th }}$ grade majoring in Science (XII \\
\hline Keywords: & $\begin{array}{l}\text { chooses the sample. It is the choosing sample technique used randomly and } \\
\text { proportionally that focused on the population's level. The method of the study }\end{array}$ \\
\hline $\begin{array}{l}21^{\text {st }} \text { Century skills; } \\
\text { Direct current circuit; } \\
\text { Metacognitive awareness; } \\
\text { Problem solving ability. }\end{array}$ & $\begin{array}{l}\text { is correlational. The study instruments are } 45 \text { Metacognitive Awareness } \\
\text { Inventory (MAI) statements and seven essay questions of problem-solving } \\
\text { ability test. The result of the Person Product Moment correlation and the } \\
\text { significant test shows that metacognitive awareness has a positive and } \\
\text { significant correlation with students' problem-solving ability to direct current } \\
\text { electricity concepts. Moreover, it is known that students' metacognitive } \\
\text { awareness and problem-solving ability are at a medium level. }\end{array}$ \\
\hline
\end{tabular}

(C) 2020 Physics Education Department, UIN Raden Intan Lampung, Indonesia.

\section{INTRODUCTION}

The 21st-century global competition requires the education sector to build students to have capable abilities. One of the abilities is problem-solving (Demirel \& Yilmaz, 2018). But in solving the problem, every student has a different ability (Huda et al., 2020; Nurjanah et al., 2017; Rahmawati et al., 2018). Palobo et al. (2018) stated the difference indicates that the students' ability is uneven and difficult for teachers to teach. Based on the interview results with the physics teacher in one of South Tangerang High School, the difficulties teachers often face when managing the learning process is because of uneven students' ability. For example, students demonstrate different problem-solving skills when faced with more complex issues than are modeled. Students with good problem-solving skills feel challenged.
Siagian et al. (2019) proposed the differentiation among students in solving the problem. It is indicated that happens because every student has different metacognitive awareness. The higher the students' metacognitive awareness level, the higher their ability to solve the problem (Izzati \& Mahmudi, 2018; Kartika \& Firmansyah, 2018; Rahman \& Hassan, 2017). Nurjanah et al. (2017), in their research on chemistry, shows that students with high, moderate, and low scores in solving problems, each having metacognitive awareness at the reflective use, strategic use, and aware use levels. These levels are thoughtful use, strategic use, intended use, and tacit use from highest to lowest.

Meanwhile, in their research in biology, Erlin \& Fitriani (2019) shows that students with less and enough metacognitive awareness criteria acquire a lower understanding ability score from the right 
criteria. It is known that understanding ability is necessarily needed to solve a problem. Amin \& Sukestiyarno (2015), in their research suggests that metacognitive awareness has a positive linear relationship with cognitive skills, where cognitive skills are the basis of compressing a person to be able to think high levels such as resolving the problem. This issue becomes why metacognitive awareness must be improved to support students' problem-solving ability improvement through the learning process in the class.

One of the learning activities that can facilitate students' metacognitive awareness and problem solving ability is physics course (Pimvichai et al., 2019). Physics problems can support students' problem-solving ability improvement because they can be found surrounding natural phenomena, both qualitatively and quantitatively. Furthermore, Surjanem (2015) also stated that in physics learning, students should master the concepts and implement the ideas in solving physics problems. One of the physics concepts that need a wellunderstanding of metacognitive awareness and problem-solving ability is direct current electricity (Kemdikbud, 2016).

However, the relationship between metacognitive awareness and problemsolving ability is presented qualitatively in mathematics, chemistry, and biology. The correlation between metacognitive awareness and problem-solving skills still needs to be proven quantitatively, especially in physics. It is supported by Ogan-Bekiroglu \& Dulger (2017) that stated the information about students' metacognitive awareness, physics problem-solving ability, and the correlation between them had not been much found. The cause why the data has not been much found is there are so few studies are done about students' metacognitive awareness in solving a physics problem. This information is essential for teachers to know because it can help them determine the appropriate teaching models that should be implemented (Setyadi, 2017). Therefore, this study aims to serve information about students' metacognitive awareness, problemsolving ability, and correlation.

\section{METHODS}

This study is an ex post facto study with a correlational method. Ex post facto is a study in which data is taken after all events have occurred, and there is no direct control from the researcher on the variables studied (Sani et al., 2018). This study aims to know the correlation between students' metacognitive awareness and problem-solving ability. The process of this study is illustrated in Figure 1 below.

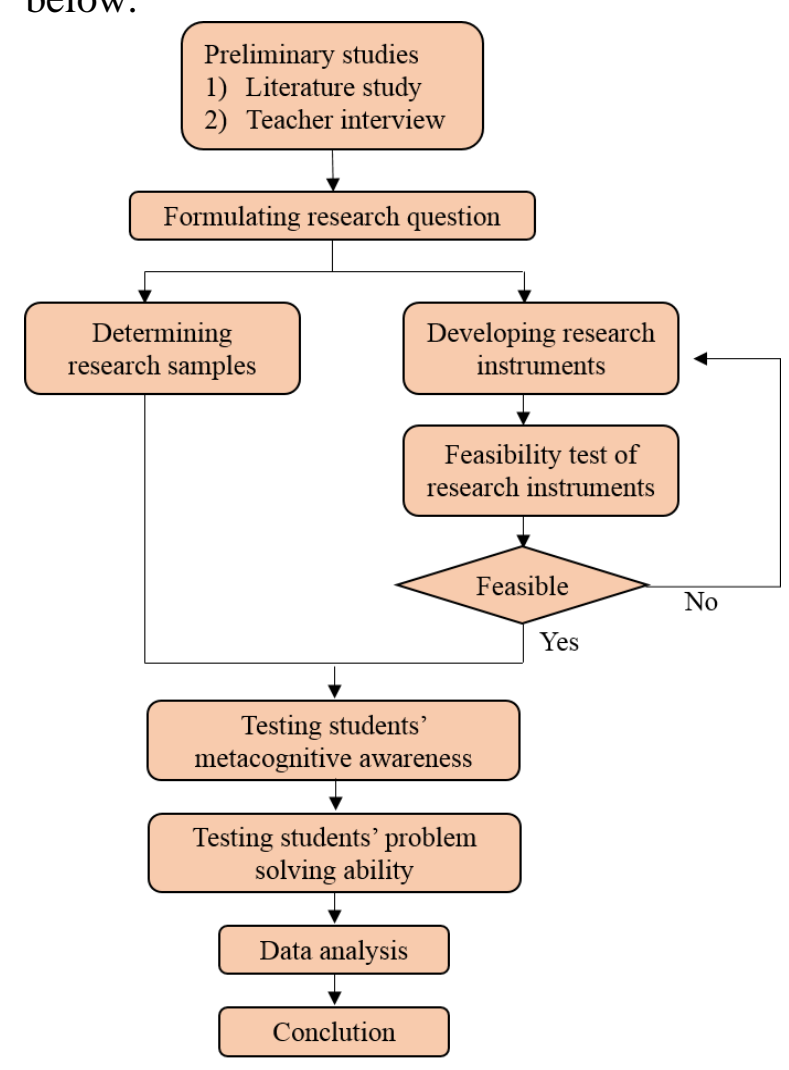

Figure 1. Flowchart of the study process

This study's population was 197 XII science program students in one of the senior high schools in South Tangerang. According to Isaac Micahel's table, the samples are 126 students chosen by using proportionate stratified random sampling technique that is a choice sample technique used randomly and proportionally that focused on the strata of the population (Sugiyono, 2013). Strata is classified into three groups: high, medium, and low (Arikunto, 2012) based on students' 
final exam scores in the academic year 20182019. The following table is the distribution sample of this study.

Table 1. Population and distribution sample

\begin{tabular}{cccc}
\hline Strata & $\begin{array}{c}\text { Amount of } \\
\text { Population } \\
\text { (Students) }\end{array}$ & $\begin{array}{c}\text { Percen } \\
\text { tage }\end{array}$ & $\begin{array}{c}\text { Amount } \\
\text { of Sample } \\
\text { (Students) }\end{array}$ \\
\hline High & 29 & $15 \%$ & 19 \\
Medium & 142 & $72 \%$ & 91 \\
Low & 26 & $13 \%$ & 16 \\
\hline Total & $\mathbf{1 9 7}$ & $\mathbf{1 0 0 \%}$ & $\mathbf{1 2 6}$ \\
\hline
\end{tabular}

The instrument that is used to count metacognitive awareness is the Metacognitive Awareness Inventory (MAI), which is improved by Schraw \& Dennison (1994) and adopted by Herlanti (2015) in rating scale form with four criteria, they are often, sometimes, seldom, and never. There are 45 statements that are ordered based on some components in Table 2.

Table 2. Metacognitive awareness components

\begin{tabular}{|c|c|}
\hline Components & Subcomponents \\
\hline $\begin{array}{l}\text { Knowledge } \\
\text { about } \\
\text { cognition }\end{array}$ & $\begin{array}{l}\text { - Declarative knowledge } \\
\text { Knowledge about one's skills, } \\
\text { intellectual resources, and } \\
\text { abilities as a learner } \\
\text { - Procedural knowledge } \\
\text { Knowledge about how to } \\
\text { implement learning procedures } \\
\text { (e.g., strategies) } \\
\text { - Conditional knowledge } \\
\text { Knowledge about when and } \\
\text { why to use learning procedures }\end{array}$ \\
\hline $\begin{array}{l}\text { Regulation of } \\
\text { cognition }\end{array}$ & $\begin{array}{l}\text { - Planning } \\
\text { Planning, goal setting, and } \\
\text { allocating resources before } \\
\text { learning } \\
\text { - Information management } \\
\text { strategies } \\
\text { Skills and strategy sequences } \\
\text { used on-line to process } \\
\text { information more efficiently } \\
\text { (e.g., organizing, elaborating, } \\
\text { summarizing, selective } \\
\text { focusing) } \\
\text { - Comprehension monitoring } \\
\text { Assessment of one's learning } \\
\text { or strategy use } \\
\text { - Debugging strategies } \\
\text { Strategies used to correct } \\
\text { comprehension and } \\
\text { performance errors. } \\
\text { - Evaluation }\end{array}$ \\
\hline
\end{tabular}

\begin{tabular}{ll}
\hline Components & \multicolumn{1}{c}{ Subcomponents } \\
\hline & $\begin{array}{l}\text { Analysis of performance and } \\
\text { strategy effectiveness after a } \\
\text { learning episode }\end{array}$ \\
\hline
\end{tabular}

Then, the result of MAI is analyzed descriptively to know students' metacognitive awareness level and their achievements in each subcomponent. The level is determined based on Table 3 .

Table 3. Metacognitive awareness level

\begin{tabular}{cc}
\hline Interval & Interpretation \\
\hline $\mathrm{X} \leq 43,75$ & Very Low \\
$43,75<\mathrm{X} \leq 56,25$ & Low \\
$56,25<\mathrm{X} \leq 68,75$ & Medium \\
$68,75<\mathrm{X} \leq 81,25$ & High \\
$81,25<\mathrm{X}$ & Very High \\
\hline
\end{tabular}

(Source: Azwar, 2018)

Furthermore, the instrument used to assess problem-solving ability is an instrument in essay form about a direct current circuit. In the assessment, there are five steps or indicators to visualize the problem, describe the physics terms, plan a solution, execute the plan, and check \& evaluate (Heller et al., 1992). The result of the problem-solving ability test will be analyzed descriptively to know students' problem-solving ability level and their achievements in each indicator. The level is determined by Table 4 .

Table 4. Problem solving ability level

\begin{tabular}{cc}
\hline Interval & Interpretation \\
\hline $\mathrm{X} \leq 25$ & Very Low \\
$25<\mathrm{X} \leq 42$ & Low \\
$42<\mathrm{X} \leq 58$ & Medium \\
$58<\mathrm{X} \leq 75$ & High \\
$75<\mathrm{X}$ & Very High \\
\hline
\end{tabular}

(Source: Azwar, 2018)

Furthermore, the data are analyzed using Pearson Product Moment Correlation analysis after passing prerequisite analysis (normality and linearity test). Correlation analysis aims to know how strong the correlation between students' metacognitive awareness and problem-solving ability. The correlation level of those variables is shown in coefficient correlation, significance, and coefficient determination. The scores of 
coefficient correlation are explained in Table 5.

Table 5. Interpretation of coefficient correlation (r)

\begin{tabular}{cc}
\hline Interval & Interpretation \\
\hline $\mathrm{r}=0$ & No correlation \\
$0<\mathrm{r} \leq 0,20$ & Very low correlation \\
$0,20<\mathrm{r} \leq 0,40$ & Low correlation \\
$0,40<\mathrm{r} \leq 0,70$ & Moderate correlation \\
$0,70<\mathrm{r} \leq 0,90$ & High correlation \\
$0,90<\mathrm{r}<1,00$ & Very high correlation \\
$\mathrm{r}=1$ & Perfect correlation \\
\hline
\end{tabular}

(Souce: Hasan, 2011)

\section{RESULTS AND DISCUSSION Metacognitive Awareness}

Based on the analysis result, there is some information about students' metacognitive awareness, as in Table 6 and Table 7.

Table 6. Students' metacognitive awareness data test centralization

\begin{tabular}{cc}
\hline Centralization of Data & Test Result \\
\hline Lowest Score & 45,56 \\
Highest Score & 90,56 \\
Mean & 67,27 \\
Standard Deviation & 9,88 \\
\hline
\end{tabular}

Table 7. The percentage of the metacognitive awareness test

\begin{tabular}{|c|c|c|}
\hline Interval & Percentage & Level \\
\hline$X \leq 43,75$ & $0 \%$ & Very Low \\
\hline $43,75<X \leq 56,25$ & $16 \%$ & Low \\
\hline $56,25<X \leq 68,75$ & $37 \%$ & Medium \\
\hline $68,75<X \leq 81,25$ & $40 \%$ & High \\
\hline $81,25<X$ & $7 \%$ & Very High \\
\hline
\end{tabular}

Table 6 shows that students' metacognitive awareness is still at a medium level. While on table 7 shows that most students' metacognitive awareness is at a medium and high level. This result is in line with previous studies (Amin \& Sukestiyarno, 2015; Erlin \& Fitriani, 2019) stated that students' metacognitive awareness is mostly medium. Jaleel \& Premachandran (2016) said if students have good metacognitive awareness, they can choose which strategy is appropriate for themselves. Students know when they use a particular strategy and how to implement it. By having this skill, students can comprehend what they have been learned by themselves favorably. According to students' metacognitive awareness test result, means that students' skill is at a medium level.

The statements above are supported by each metacognitive awareness subcomponent's achievement, as proved by following figure 2

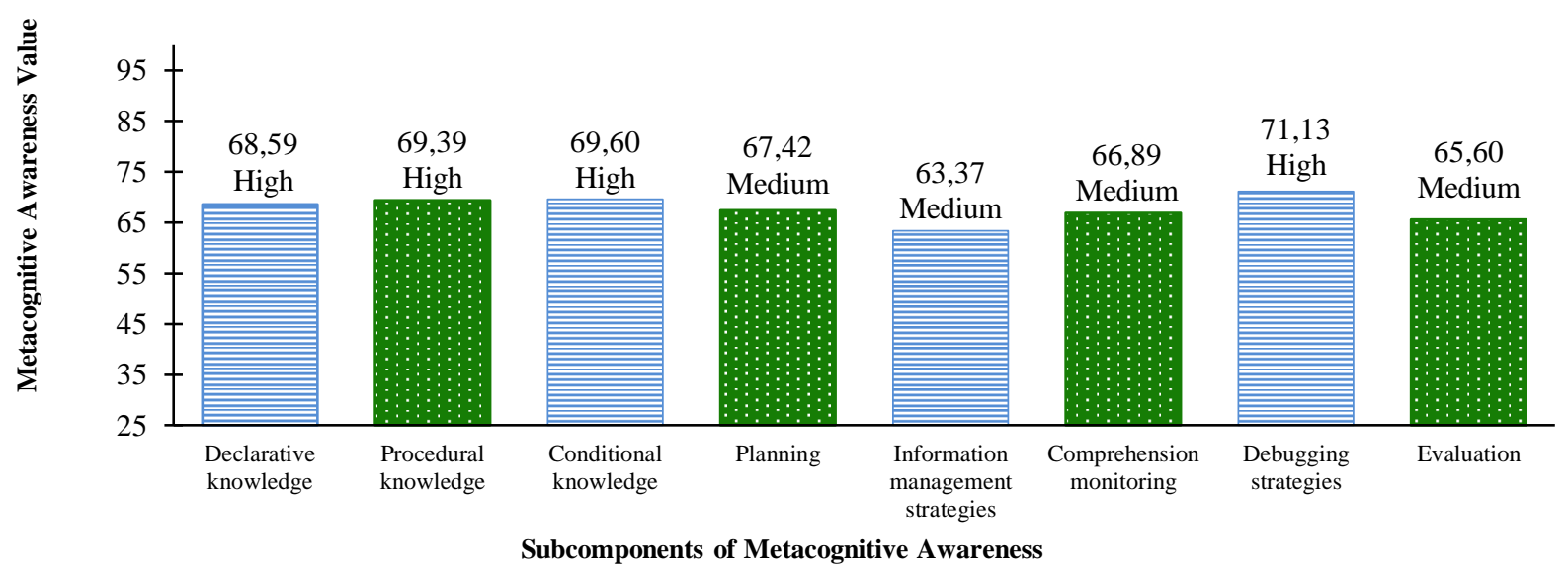

Figure 2. Achievement score of metacognitive awareness subcomponent

Based on Figure 2, there are three highest subcomponents they are procedural knowledge, conditional knowledge, and debugging strategy. High achievement of 
procedural knowledge shows that students have heightened awareness or understanding about how to implement various strategies that fit themselves. Also, conditional knowledge's high achievement shows that students know when and why they use specific strategies. While the high achievement of debugging strategy shows that students have high awareness to fix their strategies that have been used if there are some mistakes when doing an activity (Hindun et al., 2020).

Besides, they have high achievement in some subcomponents. Also, based on figure 1 shows that there are some metacognitive awareness subcomponents that are in medium levels, such as declarative knowledge, planning, information management strategy, comprehension monitoring, and evaluation. It shows that students' awareness that related to those subcomponents still needs to be improved. Declarative knowledge improvement needs to improve to enhance students' awareness and knowledge about important issues and their awareness to remember and organize those issues. Planning subcomponent needs to improve to enhance students' awareness in planning and determining a purpose as well as allocate their knowledge when studying. Information management strategy subcomponent needs to improve in order to enhance students' awareness in managing the strategy when processing some information. Some improvements need to be made in monitoring subcomponents to enhance students' awareness. Furthermore, evaluation subcomponent needs to improve in order to enhance students' awareness in evaluating their performance after doing an activity or an assignment (Hindun et al., 2020; Kallio et al., 2018). These development efforts are expected to help students make their learning activities effective or their activities in doing a task (Setyadi et al., 2016).

Setyadi et al. (2016) stated that the example of activity and assignment is a problem-solving activity. In solving the problem, students need each metacognitive awareness subcomponent to control the thinking process before, during, and after problem-solving activity (Jagals \& Walt, 2016). Before solving the problem, students need to plan the solution. In planning the solution, students need to identify and implement physics concepts and principles into equality form, then use equality to solve the problem (Apriyani et al., 2019). By the existence of metacognitive awareness, students can centralize some important information they need, plan the exact strategy, and evaluate the strategy's effectiveness so it can be a consideration to solve other problems (Kallio et al., 2018). However, since the achievement of some metacognitive awareness, subcomponents are still medium level. It causes the achievement of some problem-solving indicators is at a medium level; even some are low.

According to the analysis result, there is some information about students' problemsolving ability on a direct current circuit, as shown by following table 8 .

Table 8. Students' physics problem-solving ability data centralization

\begin{tabular}{cc}
\hline Data Centralization & Test Result \\
\hline Lowest Score & 6,77 \\
Highest Score & 90,89 \\
Mean & 56,40 \\
Standard Deviation & 20,04 \\
\hline
\end{tabular}

Based on table 8 , the mean of students' problem-solving ability in physics is medium. Moreover, the percentage of the number of students in every category can be seen in Table 9.

Table 9. Percentage of the number of students on metacognitive awareness level

\begin{tabular}{ccc}
\hline Interval & $\begin{array}{c}\text { Percentage of } \\
\text { the Number } \\
\text { of Students }\end{array}$ & Level \\
\hline $\mathrm{X} \leq 25$ & $7 \%$ & Very Low \\
$25<\mathrm{X} \leq 42$ & $20 \%$ & Low \\
$42<\mathrm{X} \leq 58$ & $29 \%$ & Medium \\
$58<\mathrm{X} \leq 75$ & $26 \%$ & High \\
$75<\mathrm{X}$ & $18 \%$ & Very High \\
\hline
\end{tabular}


Table 9 shows that the percentage of the number of students in every category is mostly at medium level. Additionally, the score of each problem-solving ability can be seen in figure 2 .

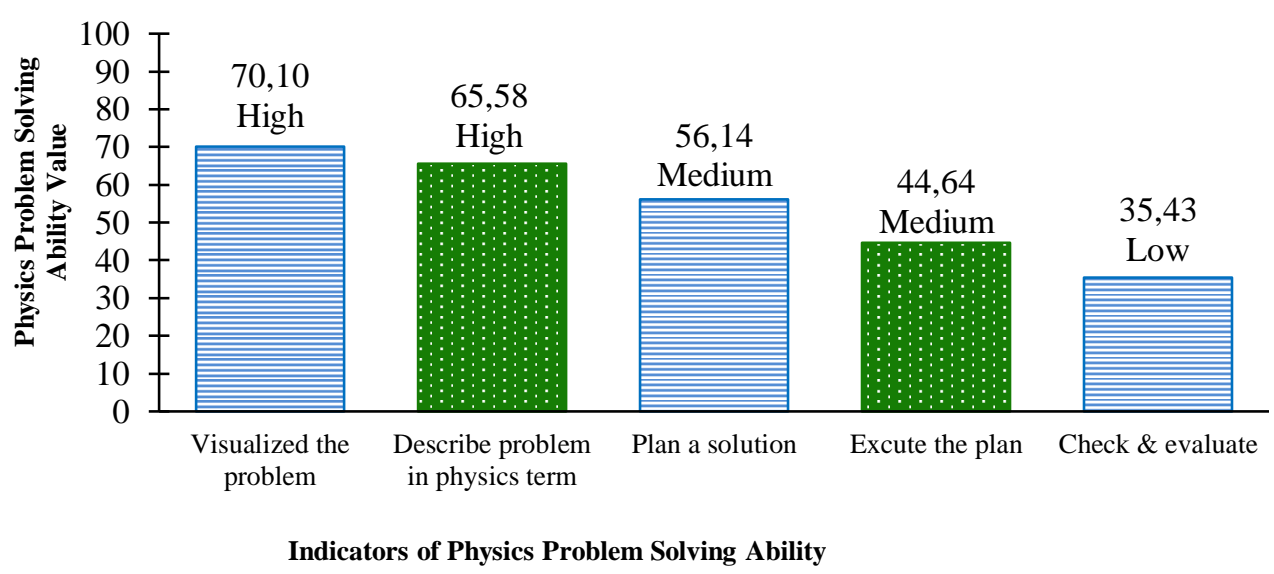

Figure 3. Achievement score of students' physics metacognitive awareness level

Figure 3 shows us that indicators of problem-solving ability that are in medium level plan a solution and execute the plan while the indicators that are in low level such as check and evaluate. Moreover, the other indicators, such as visualizing the problem and describing the physics term problem, are at a high level. Also, the analysis result shows that the indicators' achievement mostly decreases based on problem solving ability physics term steps (visualized the problem to check and evaluate) (Apriyani et al., 2019; Rokhmat et al., 2017). It means, if students have not master previous indicators or steps, then students will have trouble to master next indicators or steps. It means students' problem-solving ability still needs more improvement, mainly in planning a solution, executing the plan, checking, and evaluating.

In plan a solution, students still need to sharpen their ability when choosing the principles or the equalities of physics to solve the problem. In executing the plan, students need to train their ability to substitute variable scores into the chosen similarity. In check and evaluate, students need to train their ability when rechecking problemsolving steps related to the completeness, accuracy, and logic of the gained solution
(Apriyani et al., 2019; Permatasari et al., 2019; Rokhmat Hidayat et al., 2017)

Based on the data above, it shows that metacognitive awareness has a role in problem-solving ability. The correlation analysis result supports this statement by using the Pearson Product Moment correlation test that has been done as following Table 10.

Table 10. Result of pearson product moment correlation tests

\begin{tabular}{cc}
\hline Statistic & Test Results \\
\hline Coefficient of & 0,500 \\
Correlation $(r)$ & \\
Sig. (2-tailed) & 0,000 \\
Significance Level & 0,05 \\
\hline Determination of Coefficient $=r^{2} \times 100 \%=25 \%$
\end{tabular}

From Table 10, we can conclude that metacognitive awareness has a positive and significant correlation with problem-solving ability towards direct current circuit material. Additionally, based on the correlative coefficient score $(0,500)$, the correlation between those two categories is medium. This is in line with the previous study (Bars \& Oral, 2017; Butai \& Phang, 2018; Rahman \& Hassan, 2017; Yildirim \& Ersözlü, 2013) that there is a positive and significant correlation in medium level between 
metacognitive awareness and problemsolving ability.

This medium result is indicated because some students have high metacognitive awareness but is not used to solve the problem (Aljaberi \& Gheith, 2014). However, from the result of the study, the improvement of metacognitive awareness will be followed by the improvement of problem-solving ability. Based on the coefficient's determination, metacognitive awareness contributes $25 \%$ towards problem-solving ability at physics courses, especially on direct current circuit material.

\section{CONCLUSION AND SUGGESTION}

Based on the study results, metacognitive awareness correlates medium, positive, and significant problem-solving ability on direct current circuit material. Metacognitive awareness or problem-solving ability is at a medium level. To gain more information, it needs further sstudy with wider sources and other supporting indicators such as learning style, literacy ability, etc.

\section{AUTHOR CONTRIBUTIONS}

SR and EH wrote the manuscript, $\mathrm{EH}$ collected and analysed data. SR design the flowchart and display data.

\section{REFERENCES}

Aljaberi, N. M., \& Gheith, E. (2014). The relationship between the university students' level of metacognitive thinking and their ability to solve mathematical and scientific problems. Research on Humanities and Social Sciences, 4(15), 139-151.

Amin, I., \& Sukestiyarno, Y. L. (2015). Analysis metacognitive skills on learning mathematics in high school. International Journal of Education and Research, 3(3), 213-222.

Apriyani, R., Ramalis, T. R., \& Suwarma, I. R. (2019). Analyzing student's problem solving abilities of direct current electricity in STEM-based learning. Journal of Science Learning, 2(3), 85-
91. https://doi.org/10.17509/jsl.v2i3.17559 Arikunto, S. (2012). Dasar- dasar evaluasi pendidikan (2nd ed.). Bumi Aksara.

Azwar, S. (2018). Penyusunan skala psikologi (II). Pustaka Pelajar.

Bars, M., \& Oral, B. (2017). The relation among metacognitive awareness, selfefficacy towards teaching profession and problem solving skills of teacher candidates. Eurasian Journal of Educational Research, 17(72), 107128.

https://doi.org/10.14689/ejer.2017.72.6

Butai, S. N., \& Phang, F. A. (2018). Relationship between dimension metacognition and students' ability level in physics problems solving involving the use of free-body diagram.

The International Journal of Humanities \& Social Studies, 6(7), 252257.

Demirel, T., \& Yilmaz, T. K. (2018). The effects of mind games in math and grammar courses on the achievements and perceived problem-solving skills of secondary school students. British Journal of Educational Technology, 00(00), 1-13. https://doi.org/10.1111/bjet.12624

Erlin, E., \& Fitriani, A. (2019). Profile metacognitive awareness of biology education students in microbiology course. Journal of Physics: Conference Series, 1157(2), 1-5. https://doi.org/10.1088/17426596/1157/2/022066

Hasan, M. I. (2011). Pokok- pokok materi statistik 1 (Statistik Deskriptif) (Second). Bumi Aksara.

Heller, P., Keith, R., \& Anderson, S. (1992). Teaching problem solving through cooperative grouping. part 1: Group versus individual problem solving. American Journal of Physics Education, 60(7), 627-636. https://doi.org/10.1119/1.17117

Herlanti, Y. (2015). Kesadaran metakognitif dan pengetahuan metakognitif peserta 
didik sekolah menengah atas dalam mempersiapkan ketercapaian standar kelulusan pada kurikulum 2013. Cakrawala Pendidikan, 34(3), 357367.

https://doi.org/10.21831/cp.v3i3.7343

Hindun, I., Nurwidodo, N., \& Wicaksono, A. G. C. (2020). Metacognitive awareness components of high-academic ability students in biology hybrid learning: Profile and correlation. JPBI (Jurnal Pendidikan Biologi Indonesia), 6(1), 31-38.

https://doi.org/10.22219/jpbi.v6i1.1109 7

Huda, M. J., Florentinus, T. S., \& Nugroho, S. E. (2020). Students' mathematical problem -solving ability at realistic mathematics education (RME). Journal of Primary Education, 9(2), 228-235. https://doi.org/10.15294/jpe.v9i2.32688

Izzati, L. R., \& Mahmudi, A. (2018). The influence of metacognition in mathematical problem solving. Journal of Physics: Conference Series, 1097(1), 1-7. $\quad$ https://doi.org/10.1088/17426596/1097/1/012107

Jagals, D., \& Walt, M. Van Der. (2016). Enabling metacognitive skills for mathematics problem solving: A collective case study of metacognitive reflection and awareness. African Journal of Research in Mathematics, Science and Technology Education, 20(2), 1-11. https://doi.org/10.1080/18117295.2016. 1192239

Jaleel, S., \& Premachandran, P. (2016). A study on the metacognitive awareness of secondary school students. Universal Journal of Education Research, 4(1), 165-172.

https://doi.org/10.13189/ujer.2016.040 121

Kallio, H., Virta, K., \& Kallio, M. (2018). Modelling the components of metacognitive awareness. International Journal of Educational Psychology, $7(2)$,

94-122. https://doi.org/10.17583/ijep.2018.2789 Kartika, H., \& Firmansyah, D. (2018). Peran kesadaran metakognitif terhadap kemampuan pemecahan masalah matematis. Jurnal THEOREMS (The Original Research of Mathematics), 3(2), 99-104.

Kemdikbud. (2016). Silabus mata pelajaran sekolah menengah atas/madrasah aliyah (SMA/MA): Mata pelajaran fisika.

Nurjanah, A. I., Milama, B., \& Fairusi, D. (2017). Students Metacognitive Level on Solving Chemistry Problems. Tarbiya: Journal of Education in Muslim Society, 4(1), 63-73. https://doi.org/10.15408/tjems.v4i1.584 8

Ogan-Bekiroglu, F., \& Dulger, Z. (2017). Looking for a relationship between metacognitive awareness and problem solving skills in physics. $10^{\text {th }}$ Annual International Conference of Education, Research and Innovation.

Palobo, M., Sianturi, M., Marlissa, I., Purwanty, R., Dadi, Os., \& Nur, A. S. (2018). Analysis of teachers' difficulties on developing curriculum 2013 lesson plans. 1st International Conference on Social Sciences (ICSS 2018), 226, 1319-1324.

https://doi.org/10.2991/icss18.2018.278

Permatasari, A. K., Istiyono, E., \& Kuswanto, H. (2019). Developing assessment instrument to measure physics problem solving skills for mirror topic. International Journal of Educational Research Review, 4(3), 358-366.

https://doi.org/10.24331/ijere.573872

Pimvichai, J., Sanium, S., \& Buaraphan, K. (2019). Exploration of students' metacognitive experience in physics classroom. Journal of Physics: Conference Series, 1340(1), 1-10. https://doi.org/10.1088/17426596/1340/1/012076

Rahman, S., \& Hassan, N. (2017). Problem 
solving skills, metacognitive awareness, and mathematics achievement: A mediation model. The New Educational Review, 49(3), 201-212. https://doi.org/10.15804/tner.2017.49.3 .16

Rahmawati, D., Sajidan, \& Ashadi. (2018). Analysis of problem solving skill in learning biology at senior high school of Surakarta. Journal of Physics: Conference Series, 1006, 1-5. https://doi.org/10.1088/17426596/1006/1/012014

Resource, A., \& Guide, P. (2008). 21st century skills, education \& competitiveness (p. 13). https://eric.ed.gov/?id=ED519337

Rokhmat Hidayat, S., Hanif Setyadin, A., Kaniawati, I., Suhendi, E., Siahaan, P., $\&$ Samsudin, A. (2017). Pengembangan instrumen tes keterampilan pemecahan masalah pada materi getaran, gelombang, dan bunyi. JPPPF (Jurnal Penelitian dan Pengembangan Pendidikan Fisika), 3(2), 157-166. https://doi.org/10.21009/1.03206

Sani, R. A., Manurung, S. R., Suswanto, H., \& Sudiran. (2018). Penelitian Pendidikan. Tira Smart.

Schraw, G., \& Dennison, R. S. (1994). Assessing metacognitive awareness. Contemporary Educational Psychology, 19(4), 460-475. https://doi.org/10.1006/ceps.1994.1033 Setyadi, D., Subanji, \& Muksar, M. (2016).
Identification of students ${ }^{6}$ metacognition level in solving mathematics problem about sequence. IOSR Journal of Research \& Method in Education, 6(6), 1-7. https://doi.org/10.9790/73880606040107

Siagian, M. V, Saragih, S., \& Sinaga, B. (2019). Development of learning materials oriented on problem-based learning model to improve students' mathematical problem solving ability and metacognition ability. International Electronic Journal of Mathematics Education, 14(2), 331-340. https://doi.org/10.29333/iejme/5717

Sugiyono. (2013). Metode penelitian pndidikan: Pendekatan kuantitatif, kualitatif, dan $r \& d$. Alfabeta.

Surjanem, R. (2015). Profil keterampilan berpikir kritis dan kemampuan pemecahan masalah fisika siswa SMA negeri di kota singaraja. Seminar Nasional Pendidikan Sains UKSW, 228-233.

Yildirim, S., \& Ersözlü, Z. N. (2013). The relationship between students ${ }^{*}$ metacognitive awareness and their solutions to similar types of mathematical problems. Eurasia Journal of Mathematics, Science \& Technology Education, 9(4), 411-415. https://doi.org/10.12973/eurasia.2013.9 4 